\title{
MENINGKATKAN PEMAHAMAN NILAI PROFETIK MELALUI KONSEP INTEGRASI PEMBELAJARAN MODEL MATEMATIKA
}

\author{
Saiful Marom $\bowtie$ \\ Institut Agama Islam Negeri Salatiga
}

\begin{abstract}
Info Artikel Abstract
Sejarah Artikel:

Diterima 25Agt 2018

Direvisi 4 Sept 2018

Disetujui 29 Okt 2018

Keywords : integration learning, mathematic model, humanism, liberation, trenasendence.

Paper type: Research paper

Understanding the prophet value has a vital role for the students as the future generation of the nation.The value of prophet obtained from adopt the properties of praiseworthy of the prophet mohammed, values profetik consisting of the value of of humanism ( humanizing people, value liberation and scores transcendenceThe purpose of this study is to know the effectiveness of the integration of mathematics learning with Al-Quran to improve understanding the prophet value of the student mathematic education department of teacher training and education faculty at State Institute for Islamic Studies Salatiga. This research method used quasi experiment. The data collection technique was done by purposive sampling technique using questionnaire. The research questionnaire was developed based on the synthesis of the Revised Life Orientation Test (LOT-R). Analysis of the research results used descriptive statistics with t-test. The result of the research showed that the integration of mathematics learning with al-Qur'an can improve student'sthe prophet value significantly. The t-test between the treatment group and the control group showed a difference of $71,74 \%$ (treatment group $77,8 \%$, while the control group 6,06\%) in the improvement of student's understanding the prophet.
\end{abstract}

\begin{abstract}
Abstrak
Pemahaman mengenai hal-hal yang berkaitan dengan nilai profetik sangat penting untuk dimiliki mahasiswa untuk masa depan bangsa.Nilai-nilai profetik yang didapat dari mengadopsi sifat-sifat terpuji dari Nabi Muhammad, nilai-nilai Profetik terdiri dari Nilai Humanisme (memanusiakan manusia), Nilai Liberasi serta Nilai Transendensi. Tujuan penelitian ini adalah untuk mengetahui tingkat keefektifan integrasi pada proses pembelajaran matematika dengan ayat-ayat Al-Quran untuk meningkatkan pemahaman nilai profetik mahasiswa program studi Tadris Matematika Fakultas Tarbiyah dan Ilmu Keguruan di Institut Agama Islam Negeri Salatiga. Metode penelitian ini menggunakan quasi experiment. Teknik pengumpulan data dilakukan dengan teknik purposive sampling menggunakan kuesioner. Kuesioner penelitian dikembangkan berdasarkan sintesis dari Revised Life Orientation Test (LOT-R). Analisis hasil penelitian menggunakan statistic deskriptif dengan t-test. Hasil penelitian menunjukkan bahwa integrasi pembelajaran matematika dengan ayatayat Al-Qur'an dapat meningkatkan pemahaman nilai profetik mahasiswa secara signifikan. Uji t antara kelompok eksperimen dan kelompok control menunjukkan perbedaan $71,74 \%$ (kelompok eksperimen $77,8 \%$, sedangkan kelompok kontro 16,06\%) dalam peningkatan pemahaman nilai profetik.
\end{abstract}




\section{PENDAHULUAN}

Menurut amanat Undang-undang dalam Sistem Pendidikan Nasional di Indonesia pembentukan karakter bagi peserta didik merupakan salah satu konsentrasi dari proses pendidikan di Indonesia. Proses ini berlangsung melalui proses menyeimbangkan antara kecerdasan spiritual, emosial serta intelektual.

Menurut Zuhdi (2010) salah satu indikator dari proses pembentukan karakter bangsa yang nantinya akan menjadi suatu identitas nasional yang kuat sehingga dapat dijadikan suatu tolak ukur dari keberhasilan sebuah proses pembelajaran yang dimulai dari jenjang dasar sampai dengan jenjang pendidikan tinggi. Dengan adanya pembentukan karakter suatu bangsa sebagaimana yang telah tertuang dalam Undang-undang Sistem Pendidikan Nasional maka akan terbentuk suatu karakteristik yang khas dari setiap individu yang nantinya terwujud dalam sebuah wadah himpunan keluarga, masyarakat, bangsa serta negara. Didalam bukunya Lickona (1991) telah didefinisikan mengenai karakter yaitu suatu proses berfikir serta berperilaku dalam menjalani proses kehidupan.

Menurut Seligmen dan Peterson (1996) karakter dari manusia dapat diklasifikasikan berbagai macamjenis diantaranya yaitu optimisme, spiritualit yang baik, humor,kreatif, bersyukur, tekun, berani, disiplin, bijaksana, rendah hati, dan yang lainnya.

Selanjutnya Pembentukan karakter spiritualis penulis menurunkan nilai-nilai keislaman untuk pembentukan perilaku dan dimulai dengan menstabilkan kondisi lingkungan. Menurut kuntowijoyo (2001) dikenalkan suatu konsep pendidikan yang berlandaskan dari karakter dari Nabi Muhammad, SAW yang biasadisebut dengan karakter profetik.

Menurut Kuntowijoyo (2001) Profetik secara harfiah berasal dari kata Prophet yang mempunyai arti Nabi. Profetik dimasukkan dalam himpunan ilmu sosial yang mempunyai tiga unsur utama yaitu nilai humanisasi, nilai liberasi serta nilai transendensi. Tiga unsur utama yang membangun nilai-nilai profetik bersumber dari ayat Al Quran surat Al Imran ayat 110 yaitu :

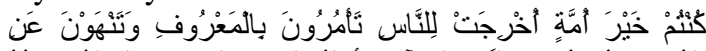

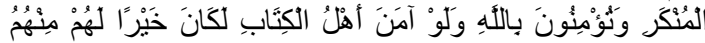

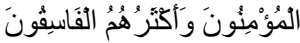

Artinya :

Engkau (Nabi Muhammad SAW) adalah umat terbaik yang diturunkan ditengah manusia untuk menegakkan kebaikan, mencegah kemungkaran (kejahatan) dan beriman kepada Allah SWT, tentulah itu lebih baik bagi mereka diantara mereka ada yang beriman, dan kebanyakan mereka adalah orang-orang fasik.

Liberasi dalam Ilmu Sosial Profetik sesuai dengan prinsip sosialisme. Hanya saja Ilmu Sosial Profetik tidak hendak menjadikan liberasinya sebagai ideologi. Liberasi Ilmu Sosial Profetik adalah dalam konteks ilmu, ilmu yang didasari nilai-nilai luhur transcendental (keimanan) yakni mencegah segala kerusakan atau dalam bahasa agamanya (Islam) adalah Nahi Munkar. Dalam Islam nahi munkar mempunyai makna mencegah segala perbuatan kejahatan atau kemungkaran. Dalam proses pembelajaran nilai liberasi dapat ditanamkan kepada peserta didik

Untuk menciptakan nilai Liberasi Ilmu Sosial Profetik dalam mengimplementasikan proses pembelajaran diperlukan suatu integrasi dari setiap rumpun ilmu. Dengan kata lain dalam proses pembelajaran untuk mengembangkan tiga aspek yakni kognitif, afektif serta psikomotorik secara berdampingan maka diperlukan suatu konsep yang telah dikembangkan oleh Abdullah (2000) yaitu konsep integrasi interkoneksi.

Munculnya konsep Integrasi interkoneksi ini diilhami dari munculnya dikotomi dari dua rumpun ilmu yakni ilmu agama dan ilmu umum (sains). Dalam proses pembelajaran dengan menggunakan konsep integrasi interkoneksi dosen memadukan ilmu yakni ilmu agama (yang tertuang dalam ayat $\mathrm{AL}$ Qur'an) dengan ilmu Umum (dalam hal ini dosen menggunakan pembentukan model matematika) sehingga dapat tercipta proses pembelajaran yang menyentuh tiga aspek.

Menurut Asfaw (2009), model matematika Ekologi merupakan suatu bagian dari konsep matematika dalam bidang ekologi yang didapatkan dari proses penerjemaham permasalahan dalam kehidupan sehari-hari yang berkaitan dengan ekologi dengan menggunakan bahasa matematik dan selanjutnya diselesaikan dengan menggunakan konsep matematika yang sahih sehingga nantinya diperoleh hasil yang selanjutnya direpresentasikan kembali kedalam bahasa sehari-hari. Dalam Proses penerjemahan diperlukan asumsi-asumsi dasar dalam berlogika yang sebenarnya sudah ada dalam ayat Al Qur'an.

Berdasarkan dari pemaparan sebelumnya maka penulis memaparkan mengenai studi tentang integrasi dalam proses pembelajaran model matematika untuk menanamkan nilai-nilai profetik. 


\section{METODE PENELITIAN}

Pada penelitian ini akan digunakan metode quasi eksperimen, yaitu dengan menggunakan obyek penelitian sebanyak dua kelas yakni kelas eksperimen dan kelas kontrol. Penelitian ini dilaksanakan di Program Studi Tadris Matematika Institut Agama Islam Negeri Salatiga. Banyaknya mahasiswa pada kelas eksperimen yaitu 36 dan banyaknya mahasiswa pada kelas kontrol 33. Sasaran dalam proses pembelajaran dengan menggunakan integrasi ini diujicobakan dalam matakuliah Model Matematika dengan topik pembehasan model mangsa pemangsa. Adapun beberapa alasan kenapa kelas tersebut dijadikan tempat penelitian ini karena dalam kelas ini mempunyai kondisi dengan tingkat homogenitas mahasiswa yang cukup baik serta dalam proses pembelajaran ini banyak konsep yang nantinya dapat membangun nilai profetik.

Untuk mengukur nilai liberasi pada konsep profetik digunakan dengan menggunakan alat ukur Revised Life Orientation Test (LOT-R) yang telah dipaparkan oleh Scheier, Carver, dan Bridges (2004). Dalam alat ukur ini berisi sepuluh pernyataan dengan empat item pengecoh. Setiap item mempunyai skala lima dengan titik awal berlabel (4) Sangat setuju dan titik akhir berlabel (0) Sangat tidak setuju. Tingkat konsistensi internal dan reliabilitas LOT$\mathrm{R}$ adalah $\alpha=0,77$ (Scheier et al, 1994).

\section{HASIL DAN PEMBAHASAN}

Pada proses pembelajaran model matematika dengan teknik integrasi dengan ayat Al Quran ini diawali dengan melakukan proses identifikasi ayat-ayat Al Qur'an yang berkaitan dengan konsep-konsep yang digunakan dalam proses pemodelan misalkan saja mengenai ekologi. Pada proses ini dosen mulai mengarahkan mahasiswa sebelum belajar pemodelan matematika untuk mereview kembali mengenai konsep tafsir tematik yang berkaitan dengan ekologi yang selanjutnya disebut dengan tafsir ekologi. Pada tahap ini para mahasiswa masih dapat mengikuti proses dengan baik dikarenakan para mahasiswa sudah mendapatkan banyak konsep keislaman yang berkaitan dengan ilmu tafsir. (dalam matakuliah tafsir, hadis, fikih, bahasa arab, dan yang lainnya.

Setelah proses identifikasi ayat yang berkaitan dengan ekologi selesai para peserta didik akan masuk kedalam proses pembangunan dasar asumsi pemodelan matematika ekologi. Dari ayat-ayat Al Qur'an yang yang berkaitan dengan ekologi maka para mahasiswa menjadikan asumsi dasar untuk menterjemahkan dengan bahasa matematika dan selanjutnya diselesaikan secara matematis dan diinterpretasikan kedalam sebuah kesimpulan.

Selanjutnya untuk melihat bagaimana dinamika yang terjadi dari model yang telah dibuat maka para mahasiswa akan diarahkan untuk membuat sebuah simulasi. Simulasi ini dapat dibuat dengan bantuan bahasa pemrograman komputer yang dianataranya adalah visual basic, turbo pascal, delphi, serta wolframs mathematica.

Selanjutnya para mahasiswa setelah melaksanakan proses pembelajaran model matematika ekologi ini dapat melihat bagaimana model matematika yang disusun dengan mengintegrasikan Ayat-ayat Al Qur'an, para mahasiswa dapat bagaimana dinamika yang terjadi pada model matematika ekologi tersebut dan masih banyak lagi.

Dengan adanya proses pembelajarn matematika dengan teknik integrasi ini maka para mahasiswa dapat tertanam nilai-nilai liberasi (misalnya berkaitan dengan dinamika alam semesta berkaitan ekologi) dari ayat-ayat Al Qur'an ini para mahasiswa dapat menghitung secara matematis bagaimana memperlakukan alam biar tetap seimbang.

Menurut Fahrudhin dkk (2018) Pemahaman konsep merupakan kemampuan yang berkaitan dengan memahami ide-ide dasar dari konsep matematika. Untuk mengukur tingkat pemahaman nilai profetik (liberasi) pada para mahasiswa di kelas eksperimen dan kelas kontrol, secara garis besar dapar disampaikan bahwa tingkat pemahaman mahasiswa berkaitan dengan nilai profetik dikedua kelas (eksperimen dan kontrol) dalam kategori tinggi $(43,47 \%)$, sedang $(52,2 \%)$, dan rendah $(4,34 \%)$. Hal ini dapat dipahami secara global bahwa para mahasiswa mempunyai pemahaman mengenai nilai profetik yang baik. Hal tersebut dapat dipaparkan dalam tabel dibawah ini :

Tabel 1. Pemahaman Nilai Profetik Kelas Eksperimen dan Kelas Kontrol.

\begin{tabular}{|c|c|c|c|}
\hline Kategori & Rentang & Frek & $\begin{array}{c}\text { Prosentase } \\
(\%)\end{array}$ \\
\hline Tinggi & $19-24$ & 30 & 43,4 \\
\hline Sedang & $13-18$ & 36 & 52,2 \\
\hline Rendah & $6-12$ & 3 & 4,34 \\
\hline
\end{tabular}

tingkat pemahaman Nilai Profetik antara kelas eksperimen dengan kelas kontrol pada studi menunjukkan bahwa ada sebuah dinamika yang dinamis pada kelas eksperimen yakni adanya tingkat pemahaman nilai profetik kelas eksperimen lebih tinggi dibandingkan dengan 
tingkat pemahaman nilai profetik pada kelas kontrol. Pada kelas eksperimen tingkat pemahaman nilai profetik kategori tinggi $(77,8 \%)$, sedang $(22,2 \%)$, dan rendah $(0 \%)$. Sedangkan tingkat pemahaman mengenai nilai profetik pada kelas kontrol pada kategori tinggi $(6,06 \%)$, sedang $(84,8 \%)$, dan rendah $(9,09 \%)$. perbedaaan antara kelas eksperimen dengan kelas kontrol ini menunjukkan bahwa penggunaan konsep integrasi pada proses pembelajaran model matematika denganayat $\mathrm{Al}$ Qur'an menunjukkan adanya signifikansi dalam meningkatkan pemahaman nilai profetik pada setiap mahasiswa. Selanjutnya akan diberikan tabel mengenai perbandingan tingkat pemahaman nilai profetik antara kelas kontrol dengan kelas eksperimen.

Tabel 2. Pemahaman Nilai Profetik Kelas Eksperimen

\begin{tabular}{lccc}
\hline Kategori & Rentang & Frek & $\begin{array}{c}\text { Prosentase } \\
(\%)\end{array}$ \\
\hline Tinggi & $19-24$ & 28 & 77,8 \\
\hline Sedang & $13-18$ & 8 & 22,2 \\
\hline Rendah & $6-12$ & 0 & 0 \\
\hline
\end{tabular}

Tabel 3. Pemahaman Nilai Profetik Kelas Kontrol.

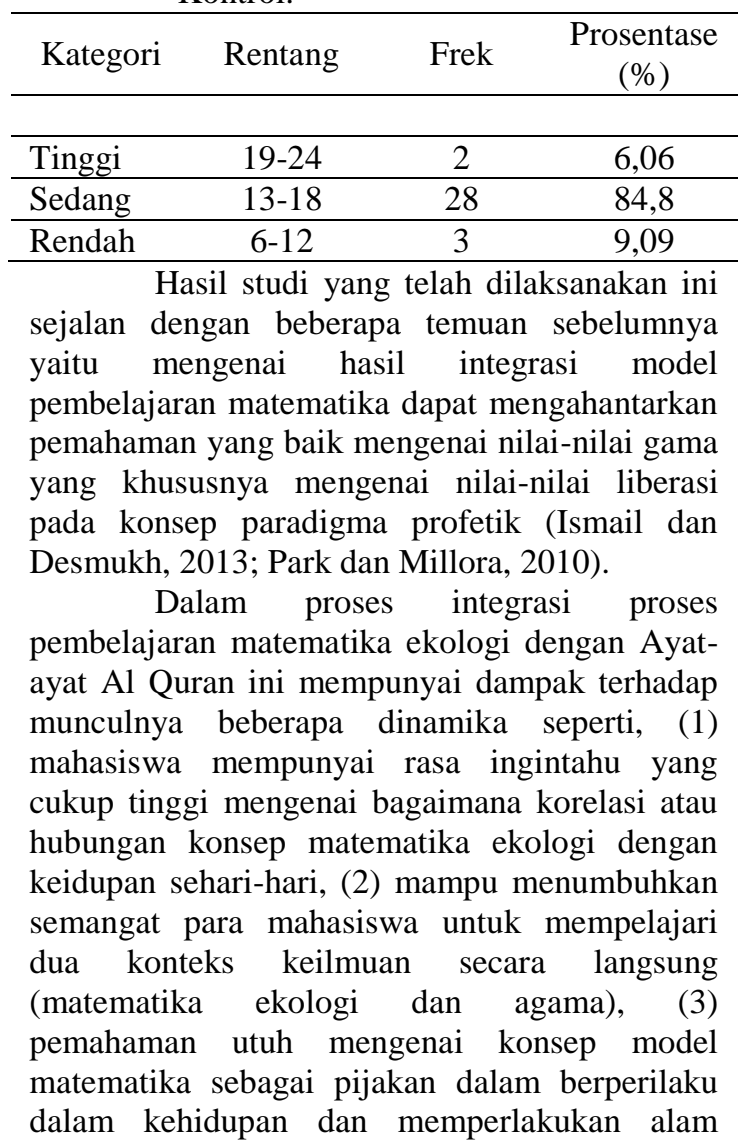

(menjaga keseimbangan alam), (4) pemahaman mahasiswa bukan hanya sekedar materi atau aspek kognitif saja melainkan dapat menyentuh aspek yang lain yaitu afektif dan psikomotorik.

Selanjutnya akan ditegaskan kembali bahwa proses pembelajaran model matematika ekologi yang terintegrasi dengan ayat Al Quran mempunyai dampak positif bagi para mahasiswa yakni meningkatnya pemahaman agama, serta munculnya emosi positif. Dampak tersebut mempunyai kontribusi yang besar bagi peningkatan dari kualiatas proses pembelajaran matematika khususnya model matematika ekologi.

\section{SIMPULAN}

Integrasi proses pembelajaran model matematika ekologi dengan Ayat-ayat Al Qur'an mampu meningkatkan pemahaman mahasiswa mengenai nilai profetik sebesar 71,74\%. Hasil peningkatan ini dipengaruhi faktor dari pemahaman ilmu agama yang kuat. Integrasi model pembelajaran ini menjadi bermakna apabila dosen danmahasiswa sama-sama mengetahui mengenai ilmu agama sehingga konsep pembelajaran model integrasi ini dapat terlaksana dengan baik.

\section{UCAPAN TERIMAKASIH}

Penulis ucapkan banyak terima kasih kepada segenap pengurus Jurnal Anargya sehingga dapat dipublikasikannya karya ini, serta tak lupa penulis ucapkan terima kasih kepada Institut Agama Islam Negeri Salatiga yang telah memberikan fasilitas pendanaan penelitian ini.

\section{DAFTAR PUSTAKA}

Asfaw, T. M. 2009. Dynamics of generalized time dependent predator-prey model with nonlinear harvesting, International Journal. Mathematic Analysis, 3, 14731485.

Bell, Frederick H. 1981. Teaching and Learning mathematics (in secondary schools). Wm. C. Brown Company. IOWA.

Birkhoff, H. and Rota, G.C. 1989.Ordinary Differentials Equations, $4^{\text {th }}$ Edition, John Wiley \& Sons, Inc, New - York.

Facrudhin GA, Zuliana E, dan Bintoro HS, 2018. Peningkatan Pemahaman Konsep Matematika Melalui Realistic Mathematic Education Berbantuan Alat Peraga BONGPAS. Anargya Jurnal Pendidikan Matematika UMK Kudus. (1): 15-20. 
Kuntowijoyo. 2001. Muslim Tanpa Masjid. Mizan. Bandung.

Lickona T. 1992. Educating for Character, How Our Schools Can Teach Respect and Responsibility . Bantam Books. New York.

Scheier MF, Carver CS, and Bridges MW 2004. Distinguishing optimism from neuroticism (and trait anxiety, self-mastery, and selfesteem): a reevaluation of the Life Orientation Test. J. of Personality and Social Psychology.IOWA

Zuchdi, D. 2010. Pengembangan Model Pendidikan Karakter Terintegrasi dalam Pembelajaran Bidang Studi Sekolah Dasar. Jurnal Cakrawala Pendidikan. UNY Yogyakarta, (2) : 1-9. 